\title{
REVIZORSKE FIRME U SRBIJI 2018.
}

\section{EKONOMIJA SRBIJE - BAZA DEJSTVA REVIZORSKIH FIRMI}

\section{Stanje ekonomije i uticaj na revizorske firme Srbije}

Revizorske firme Srbije su deo ekonomskog i socijalnog tela Srbije, i stanje ovog tela i svi njegovi kvaliteti i nedostaci neminovno deluju na stanje revizorskih firmi. Njihov položaj i ekonomske performanse su, dakle, predodređene ovim

\section{STANJE EKONOMIJE SRBIJE I REVIZORSKE FIRME}

Stanje ekonomije tokom 2018. godine značajno je uticalo na položaj i ekonomske perfomanse revizorskih firmi Srbije.

Davno nije u Srbiji bila iskazana tako visoka stopa rasta BDP kao u prethodnoj godini. $\mathrm{U}$ kojoj meri se to odrazilo na stanje revizorskih firmi u Srbiji? Svakako da jeste

Vidi str. 21-24

\section{TOP 10}

\section{REVIZORSKIH FIRMI SRBIJE}

Grupa Top 10 revizorskih firmi, koja čini V4 uz dodatak šest ostalih najjačih firmi je kardinalno značajna za finansijsko izveštavanje Srbije. Top 10 firmi ostvaruje apsolutnu dominaciju na tržištu revizorskih i sličnih usluga.

Top 10 revizorskih firmi predstavljeno je u nekoliko najznačajnijih obeležja, a kriterijum prihoda je najvažniji.

Vidi str. $24-28$

\section{PARETO POGLED NA REVIZORSKE FIRME U SRBIJI}

Pareto analiza je moćno oruđe za otkrivanje bitnih neravnomernosti inputa i autputa $u$ svakoj delatnosti. To moćno oruđe je aktivirano na populaciji revizorskih firmi Srbije.

Naravno da nije sve u apsolutnoj usklađenosti sa Paretovim nalazima, ali sve demonstrira valjanost tih analiza.

Vidi str. 26-27

\section{VELIKA ČETVORKA U SRBIJI}

Globalna dominacija Velike četvorke ima svojeg pandana u Srbiji. Dakle, one i ovde dominiraju.

Dominacija da, ali kakva su sve obeležja njihovih performasi, to je pitanje konkretnih okolnosti. U odnosu na Veliku četvorku, sva ostala populacija revizorski firmi se bori da poboljša svoju poziciju. Nadmoć V4 je demonstrirana kroz podatke za 2018. godinu.

Vidi str. 28-31

\section{REZIME}

Revizorske firme Srbije su tokom 2018. iskazale dalje uspone. Profesija se konsoliduje, kontrole nad njom neprekidno jačaju poboljšanjem institucionalizacije i jačim prisustvom kod revizora. Cene su i dalje depresivne, a procedure sve zahtevnije. Reakcija revizora je u usavršavanju i produktivnijem pristupi rešavanju pitanja revizije.

U samoj populaciji revizora neprekidne su promene, svaka firma nastoji da se snađe što bolje u iznalaženju rešenja i pridobijanju klijenata, $s$ jedne strane, i u razvijanju procedu$\mathrm{ra}$, s druge strane. Konkurencija među njima odvija se svim legalnim sredstvima i zato ne čudi da se redosled uspešnosti među njima svake godine menja. Sve to je u službi višeg kvaliteta finansijskih informacija. $\mathrm{U}$ radu su prezentirane, vrlo suvim jezikom, brojke koje predstavljaju bitne odlike populacije revizorskih firmi u Srbiji u 2018. godini.

Dr Gordana Mrdak, docent na Fakultetu za diplomatiju i bezbednost, Univerzitet „Union - Nikola Tesla“ u Beogradu, email: gordanamrdak@gmail.com 
stanjem. Ali, nikako i konačno određene. Nivo razvijenosti ekonomske sredine i njene politike usmeravanja ekonomije deluju na sve entitete $\mathrm{u}$ Srbiji, pa tako i na revizorske firme.

Srbija je u 2018. okončala trogodišnji aranžman sa MMF-om, koji je bio značajna podrška njenim reformskim poduhvatima, pri čemu se sve odigravalo u skladu s očekivanjima.

Glavne strukturne promene u ekonomiji Srbiji su izvedene, a Svetska banka uvek nanovo naglašava potrebu neprekidne dogradnje. Test svih kvaliteta ekonomskog sistema je njegova snaga da podstiče razvoj, stvarajući povoljnu klimu domaćim investitorima i otvarajući vrata stranim. Bruto domaći proizvod je, posle duže vremena, dostigao stopu rasta od 4,3\%. Međutim, analize otkrivaju da je ekonomija Srbije još uvek manja nego što je bila pre ulaska u promene tokom 90 -ih godina, dok su druge slične zemlje Evrope uvećale volumen svoje ekononomije za oko $80 \%$, kaže se u specijalnom izeštaju Svetske banke (4), čija je namera da se pomogne dostizanje stope razvoja $5-7 \%$ i duplira dohodak po glavi stanovnika u narednih 10-15 godina. $\mathrm{U}$ drugom materijalu Svetske banke $(5,2)$ se kaže da su dva talasa strukturalnih reformi dovele Srbiju na nivo koji su male ekonomije Evrope dostigle u 1996. godini, a da je sada na redu treći talas kojim bi kumulirane reforme trebalo da daju značajne efekte. Ali, to ne ide samo od sebe, potrebna je nova strategija. Tri su poluge koje tome treba da doprinesu: akumulacija kapitala, bolja upotreba radne snage i veća produktivnost.

Dakle, 2018. godina je bila godina visoke stope rasta $(4,3 \%$, koja stoji u jakom kontrastu prema godišnjem proseku od $1,2 \%$ u prethodnoj deceniji), ali je to i godina mnogih sagledavanja i traženja načina da se podstakne jači razvoj i smanje velike razlike $u$ odnosu na slične države u okruženju koje su oštrijim koracima uspešno prešle tranziciju, a koja kod nas i dalje nije kompletirana. Bila je to godina mnogo izrazitije zakonodavne dinamike, mnogih podsticajnih mera razvoja, modernizovanja državne uprave i lokalne samouprave.

Bankarski sektor je 2018. imao najbolje perfomanse u prethodnoj deceniji, kreditiranje je počelo da se intenzivira, ali firme koje imaju potencijal razvoja još nemaju adekvatnu podrš$\mathrm{ku}$. Strane investicije su dostigle relativno visok nivo, što znači da se vraća poverenje $\mathrm{u}$ sistem. Zarade $\mathrm{u}$ javnom sektoru su po prvi put nakon niza godine dobile osnovu za rast. I pored toga, i da je održiva stopa rasta iz ove godine, ona ne obezbeđuje zadovoljavajuću dinamiku hvatanja koraka sa drugim svetom.

Srbija je u velikom zaostatku kako za svojim potencijalom za rast, tako i u odnosu na komparativne države. Put ka hvatanju koraka sa svetom su odlučne reforme, otvaranje prostora za prepoznate nosioce dinamike rasta i razvoja, koje treba da se odvija ne u zastarelim industrijama, već u modernim tehnolo- 
gijama i industrijama zasnovanim na najsavremenijim tehnologijama. Stoga, srce nove strategije moraju biti: bolji finansijski sektor, viša sposobnost zaposlenih, jača konkurentska snaga i viša efektivnosti države.

\section{Stanje revizorskih firmi}

Opšte je usvojeno gledište da su revizorske fime faktor ne samo zdravog finansijskog izveštavanja, nego i stabilnosti čitavog sistema. Zakonomerno se javlja potreba za sve sofisticiranijim uslugama revizije, mimo onih koje su klasika: revizija standardnih godišnjih izveštaja. Više pažnje reviziji doneće više pažnje finansijskim izveštajima. Sigurno je bilo napretka u 2018. godini, sigurno je unapređen kako kvalitet revizije u Srbiji, tako i gledanje uprave izveštajnih entiteta na potrebu za višim kvalitetom finansijskih in-

Finansijsko izveštajno okruženje se sve bolje institucionalizuje, a revizori su u stalnoj potrazi za unapredenjima. formacija. Revizija je globalno pod jakim pritiskom redefinisanja i traženja puteva da bude faktor strategije i viših uspona.

Revizorske firme su tokom 2018. godine ispoljile sledeće bitne karakteristike.

- Stabilizovano brojno stanje revizorskih firmi. Srbija nikada nije imala inflaciju sa brojem revizora i revizorskih fir$\mathrm{mi}$, što znači da nije bilo nekontrolisanih izletanja, već je sve rađeno sa visokom odgovornošću i orijentacijom na kvalitet. Nije zato slučajno da je brojno stanje revizorskih firmi u Srbiji stabilno.

- Dalji porast prihoda revizorskih firmi u 2018. u odnosu na prethodne godine. Ako raste $\mathrm{BDP}$, prirodno je da rastu i prihodi od usluga revizije. To se dogodilo i u prethodnoj godini. Najveći doprinos rastu, a to znači i zahvatanju prihoda, dala je V4.

- Izmakla godina očekivanja promena regulacije. Strategijom razvoja finansijskog izveštavanja za Srbiju 2018. godina je označena kao godina okončanja mnogih reformi. Međutim, to je izmaklo. Izostalo je donošenje dva kardinalna zakona koja regulišu finansije: Zakona o računovodstvu i Zakona o reviziji. Sva je prilika da će se taj poduhvat okončati u ovoj godini, čime ćemo se uskladiti na najnovijom EU regulativom.

- Konsolidacija revizorskih firmi po svim dimenzijama. Revizorske firme su vitalno važne za sigurnost finansijskog izveštavanja, i prirodno je da su one centar regulative $i$ neprekidnog pooštravanja kontrole nad njihovim delovanjem. Polako se akumulira znanje, a pod pritiskom niskih cena uvode se mnoge produktivističke metode.

- Kapacitiranje revizorskih firmi je proces koji stalno napreduje. Broj angažovanih ovlašćenih revizora kao i zaposlenih je porastao, mladi ljudi preovlađuju ne samo u operativi, 


\section{ZNAČAJ TOP 10 FIRMI}

Njihov značaj je kardinalan. Podaci govore da su oni kumulacija najvišeg znanja i da presudno utiču na kvalitet finansijskog izveštavanja u Srbiji. One pokrivaju po svim obeležjima najznačajnije emitente finansijskih izveštaja. U kritično važnim obeležjima, njihov kvantitativno iskazani značaj prelazi preko $80 \%$ onog što revizija radi. Njihov uticaj na kvalitet finansijskog izveštavanja, otuda i na stabilnost ekonomije, sigurno prelazi ono što se kvantitativno izražava. nego i u vođenju revizorskih firmi. Uz ljudski faktor ide jačanje IT struktura i programa sa kojima revizori operišu.

- Jačanje kvaliteta rada revizora. Kvalitet rada revizije je centralni interes društva, kao i regulative, taj kvalitet se postiže sve zahtevnijim standardima revizije, sve boljim metodama i procedurama rada. Revizor je ključni faktor i sve se radi da se njegov kvalitet rada unapredi.

- Snažan pritisak na restrukturiranje usluga u reviziji. Prilike niskih cena i ugrožavanje opstanka revizije snažan su podsticaj da se usluge koje revizija daje prošire izvan kruga statutarnih revizija. Ovo je jak pritisak da se krene u nova područja usluga i da se kapitalizuju bitna znanja stečena u standardnoj reviziji.

\section{TOP IO FIRMI PO KLJUČNIM PARAMETRIMA}

\section{Top 10 po prihodima}

Prvih 10 revizorskih firmi su one koje prisvajaju preko četiri petine prihoda cele populacije revizora Srbije, koje nose proporcionalno daleko najveći teret revizije, i koje zbog toga zaslužuju posebnu posmatračku pažnju. Dajemo ključne karakteristike ovog segmenta revizorskih firmi Srbije.

\begin{tabular}{|c|c|c|c|}
\hline Deloitte & & & 15,831 \\
\hline KPMG & & & 15,019 \\
\hline PWC & & 8,835 & \\
\hline$E \& Y$ & & 6,186 & \\
\hline BDO & 2,408 & & \\
\hline Moore Stephens & 1,589 & & \\
\hline PKF & 822 & & \\
\hline Crowe RS Advisory & 750 & & \\
\hline Euroaudit & 687 & & \\
\hline DFK Konsultant & 683 & & \\
\hline
\end{tabular}

Posle kratkog odsustva, na čelu kolone revizorskih firmi Srbije ponovo je stao Deloitte. Poredak prvih 10 se menja $\mathrm{u}$ tome što je prošlogodišnji drugi zauzeo prvu poziciju, što znači da je KPMG sišao blago ispod Deloitte. U Top $10 \mathrm{su}$ po prvi put ušli Crowe RS i DFK konsultant. Sa liste su ispali RSM SERBIA i MC Global audit.

Deloitte ima dominantnu poziciju. Lider $u$ ovoj godini iza sebe ima sledbenike u KPMG, PWC i E\&Y. Prve četiri firme su u prethodnoj godini prisvojile preko 46 miliona EUR.

\section{Top 10 po rastu prihoda}

Rast prihoda, meren odnosom ostvarenja u ovoj u odnosu na prethodnu godinu, jeste iskaz dinamike koju su pojedine revizorske firma ostvarile u godini u odnosu na prethodnu.

Najdinamičniji porast, gledajući u masi, ostvarila je firma Crowe RSM Adevisory, koja je više nego duplirala svoj godišnji prihod. DFK Konsultant - Revizija ima veoma visoku stoplu rasta od skoro 39\%. Slede PWC i PKF sa oko jedne petine uve- 
ćanog prihoda, potom Moore Stephens sa $17,5 \%$, Deloitte sa $13,5 \%$, Krestom sa preko $8 \%$, RSM SERBIA sa nepunih $7 \%$ i KPMG sa $1,44 \%$ uvećanja.

$\mathrm{Na}$ listi je devet, a ne 10 top revizorskih firmi, po ovom kriterijumu. Razlog je u tome što među onima koji imaju 500 hiljada evra nema 10. kandidata.

Naravno, visoke stope rasta dobijaju

Crowe RS Advisory

DFK Konsultant

PWC

PKF

Moore Stephens

Deloitte

Kreston MDM

RSM SERBIA

KPMG
$38.64 \%$

$20.77 \%$

$19.23 \%$

$17.57 \%$

$13.45 \%$

$8.20 \%$

$6.87 \%$

$1.44 \%$ drugačiju dimenziju kada se uzme činjenica da je recimo Deloitte porastao za $13,5 \%$, što mu je donelo porast prihoda od skoro dva miliona evra.

\section{Top 10 po broju zaposlenih}

Rast prihoda revizorskih firmi u 2018. godini je praćen uvećanjem broja zaposlenih. $U$ odnosu na prethodnu godinu je zabeležen porast ukupnog broja zaposlenih u revizorskim firmama. To uvećanje je osetnije kod većih firmi nego kod ostalih. Uvećanje broja zaposlenih u reviziji dolazi dobrim delom zbog sve delikatnijih procedura revizije, a mnogo manje zbog uvećanja broja klijenata. Zbog primene novih pravila EU, sve veći broj firmi je izuzet iz obaveza angažavanja revizora radi atestiranja finansijskih izveštaja. Su-

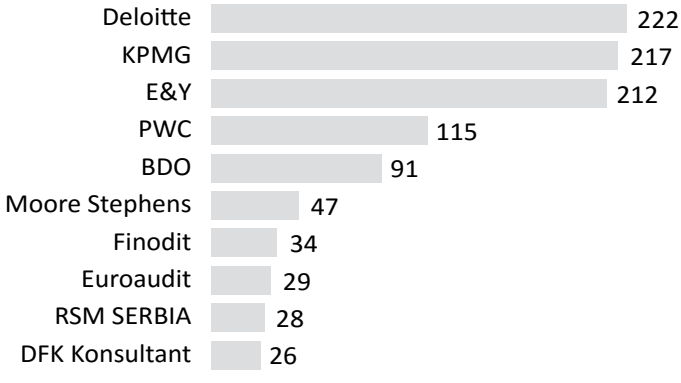
protno od ovoga deluje faktor uvećanja svesti uprave $u$ entitetima koja je zadužena za ispravno finansijsko izveštavanje.

\section{Top 10 po prihodu po zaposlenom}

Prihod po zaposlenom je posledica brojnih uticaja, među kojima su najznačajniji: vrednost sklopljenih poslova, asortiman usluga koje se ispostavljaju, organizacija posla, produktivnost u obavljanju poslova... Od V4 na listi 10 onih koji imaju najveći prihod po zaposlenom nalaze se tri firme, a četvrta je očigledno u krizi koja se ispoljava u izostanku sa ove liste. Reč je o E\&Y, koji $\mathrm{u}$ ovoj, u odnosu na prethodnu godinu ima veoma značajan pad prihoda. U svakom slučaju, tri firme iz kruga V4 (PWC,

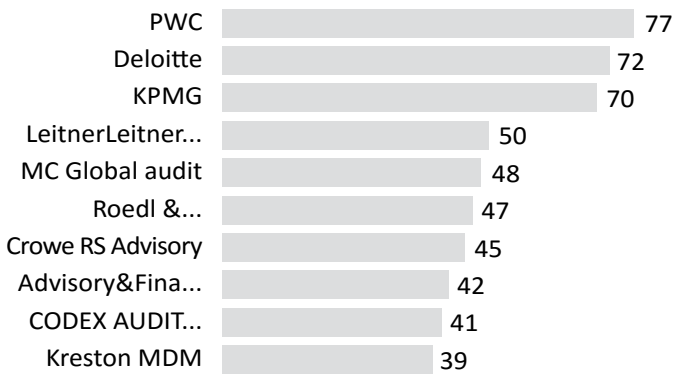
Deloitte i KPMG) ostvarile su prihod po zaposlenom u rasponu od 70 do 77 hiljada evra. Među njima i nisu tako značajne razlike. Ako se uzme prvi sa ove liste (PWC) i uporedi sa desetim, dobije se raspon od skoro dva prema jedan. 


\section{PARETO I SRPSKE}

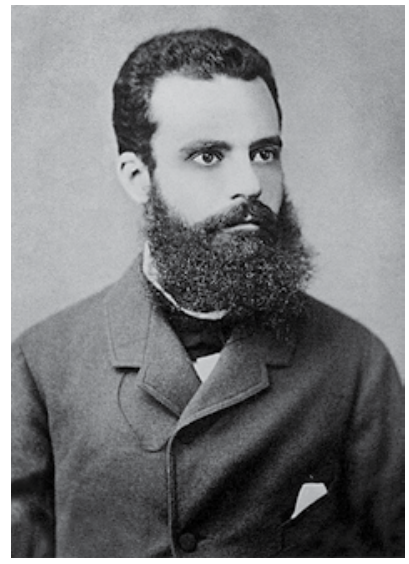

Vilfredo Pareto (1843-1923), italijanski ekonomista, istraživao je, pored ostalog, raspored bogatstva u Engleskoj $i$ tako utordio zakon po kome $20 \%$ stanovnika prisvaja $80 \%$ prihoda. Istražujući taj raspored na slučajevima drugih nacija, poturdio je važenje zakona. Proširivanjem istraživanja na druge socijalne fenomene Pareto je utvrdio da taj zakon jednako važi i za njih. Sledeći njegove nalaze danas je ustanovljeno opšte usvojeno pravilo: Bitna manjina uslova ili faktora ima preovlađujući uticaj na većinu rezultata. I obrnuto: Preovlađujuća većina uslova ili faktora produkuje manjinu rezultata.

Da vidimo kako se to demonstrira na populaciji revizorskih kuća u Srbiji u 2018. godini.

\section{0-20 Pravilo rasporeda prihoda po firmama}

$20 \%$ firmi prisvaja $80 \%$ prihoda $80 \%$ firmi prisvaja $20 \%$ prihoda

Pareto kaže: $20 \%$ ukupnog broja firmi prisvaja $80 \%$ ukupnog prihoda, a $80 \%$ firmi prisvoji $20 \%$ tog prihoda.

Podaci kažu: Od ukupnog prihoda revizorskih firmi Srbije, u iznosu od 61,40 mil EUR, 20\% firmi - njih 14 prisvaja 54,80 mil EUR ili $89,10 \%$,

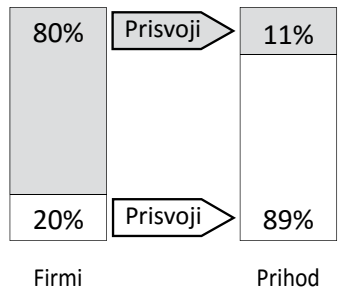
dok njih $80 \%$ prisvaja 6,70 mil EUR, odnosno $10,90 \%$ od prihoda svih revizorskih firmi.

\section{0-20 Pravilo rasporeda profita po firmama}

$20 \%$ firmi upošljava $80 \%$ profita $80 \%$ firmi upošljava $20 \%$ profita

Pareto kaže: 20\% ukupnog broja firmi prisvaja $80 \%$ profita, a $80 \%$ firmi prisvaja $20 \%$ profita.

Podaci kažu: Od ukupnog profita koji prisvoje revizorske firme, koji iznosi 2,60 mil EUR, $20 \%$ njih prisvoji 1,2 mil EUR, odnosno $46,81 \%$, dok $80 \%$ firmi prisvoji $53,19 \%$

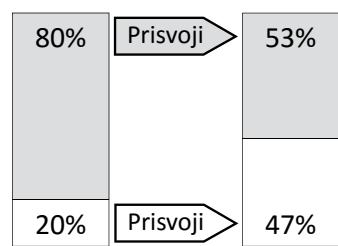

Firmi Dobitka profita, odnosno 1,40 mil EUR profita.

\section{0-20 Pravilo rasporeda imovine po firmama}

$20 \%$ firmi upošljava $80 \%$ imovine $80 \%$ firmi upošljava $20 \%$ imovine

Pareto kaže: $20 \%$ firmi poseduje $80 \%$ imovine, a $80 \%$ firmi poseduje $20 \%$ imovine.

Podaci kažu: Od ukupne imovine svih firmi, koja iznosi 40,707 mil EUR, $20 \%$ firmi poseduje $75,45 \%$, odnosno 30,70 mil EUR imovine, dok $80 \%$ firmi poseduje $9,90 \mathrm{mil}$ EUR, odnosno $24.55 \%$ ukupne imovine.

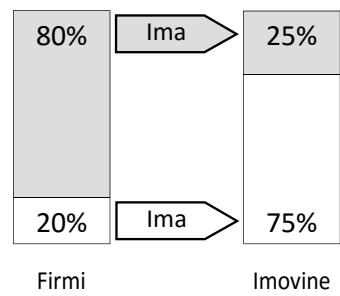

Podaci kojima demonstriramo valjanost Paretovog zakona ukazuju na to da je on zaista relevantan i za srpsku populaciju revizorskih firmi. Nije reč o tome da se svugde iskaže striktna proporcija 20 prema 80 , već da se vidi da je to tendencija koja se održava kao pravilo. Oscilacije ne znače negaciju pravila, već samo tendencijsku ispravnost. Suština koja stoji iza kvantitativne demonstracije zakona je da postoji neravnomernost uslova i efekata. 


\section{REVIZORSKE FIRME}

\section{0-20 Pravilo rasporeda kapitala po firmama}

$20 \%$ firmi poseduje $80 \%$ kapitala $80 \%$ firmi poseduje $20 \%$ kapitala

Pareto kaže: $20 \%$ od broja firmi poseduje $80 \%$ kapitala, a $80 \%$ firmi poseduje $20 \%$ kapitala.

Podaci kažu: Od ukupnog kapitala u iznosu od 14,40 mil EUR, $20 \%$ firmi poseduje 8,65 mil EUR, odnosno $60 \%$, dok $80 \%$ preostalih firmi poseduje $40 \%$, odnosno 5,77

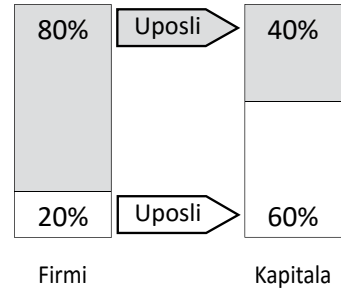
mil EUR kapitala

\section{0-20 Pravilo rasporeda zaposlenih po firmama}

$20 \%$ firmi upošljava $80 \%$ zaposlenih $\mathbf{8 0 \%}$ firmi upošljava $20 \%$ zaposlenih

Pareto kaže: 20\% firmi zaposli 80\%, a $80 \%$ firmi zaposli $20 \%$.

Podaci kažu: Od ukupno zaposlenih, što iznosi 1.424, 20\% firmi zaposli 77,32\%, odnosno 1.101 čoveka, dok $80 \%$ firmi zaposli njih 323 , odnosno $22,68 \%$ od ukupno zaposlenih.

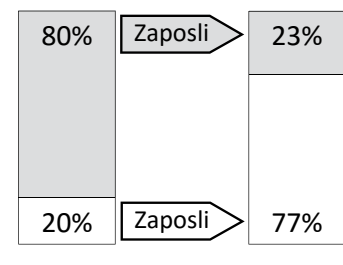

Firmi Zaposlenih

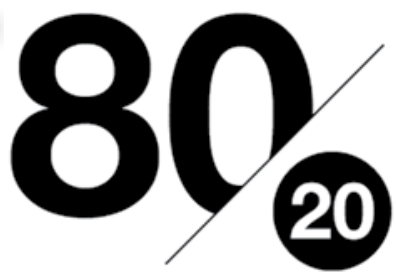

\section{0-20 Pravilo rasporeda ovlaš. reviz. po revizor. firmama}

$20 \%$ firmi zaposli $80 \%$ ovlašćenih revizora

$80 \%$ firmi zaposli

$20 \%$ ovlašćenih revizora

Pareto kaže: $20 \%$ od broja firmi zaposli $80 \%$, a $80 \%$ firmi zaposli $20 \%$ ovlašćenih revizora.

Podaci kažu: Od ukupnog broja ovlašćenih revizora, koji iznosi 264, $20 \%$ firmi zaposli 118 , odnos-

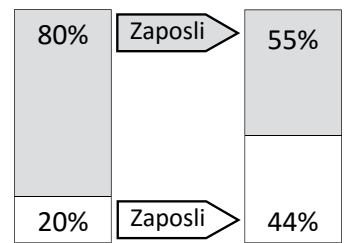

Firmi Ovlašćenih no 44,70\%, dok 80\% preostalih firmi zaposli 55,30\%, odnosno 146 ovlašćena revizora.

Dakle, i za populaciju revizorskih firmi Srbije važi Paretov zakon 80:20, što znači da:

- Bitna manjina revizorskih firmi ima preovlađujući uticaj na većinu rezultata. Ta bitna manjina zahvata većinu rezultata.

- Preovlađujuća većina produkuje manjinu rezultata. Ona ima nesrazmerno veće uloge faktora za manje rezultate.

- Uopšte, kao i na slučaju revizorskih firmi Srbije, demonstrira se pravilo da nema srazmere činilaca ulaganja i efekata, vlada pravilo nesrazmere.

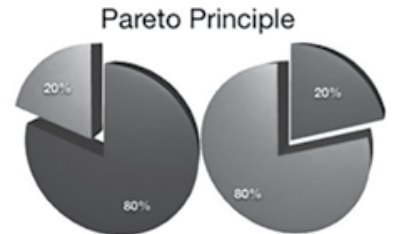

$20 \%$ of the input (time, resources, effort) accounts for $80 \%$ of the output (results, rewards) 


\section{Top 10 po broju ovlašćenih revizora}

Broj revizora po revizorskim firmama varira u zavisnosti od mase usluga koju ove obave $\mathrm{u}$ toku godine, kao i od niza dru-

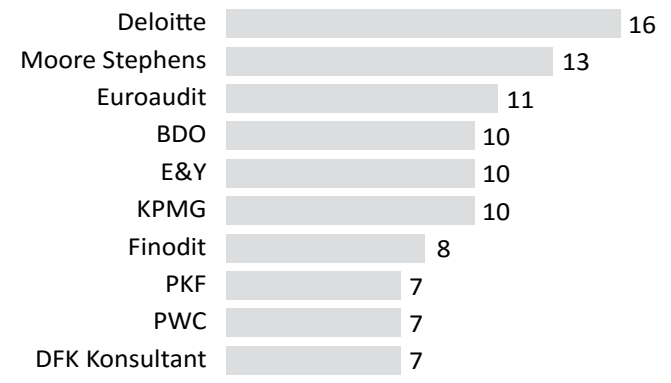
gih faktora specifičnih za datu firmu. $\mathrm{Na}$ prvom mestu po broju ovlašćenih revizora je firma koja je na prvom mestu po ostvarenim prihodima. Razlike u odnosu na druge sa ove liste ne znače i razlike $u$ prihodima, jer odnos nije pravolinijski.

Iza Deloitte je Moore Stephens, koji je u prihodima manji za preko 10 puta od nje. Dakle, nema paralelizma na relaciji veličina prihoda - broj ovlašćenih revizora. Vredno je takođe primetiti da je PWC na devetom mestu, iako je po prihodima na trećem.

Dakle, iz mnogih razloga, prihodi po zaposlenima nisu u bliskoj vezi sa prihodima, odnosno redosled u prihodima po ovim obeležjima se ne poklapa.

\section{Top 10 po prihodu po ovlašćenom revizoru}

Prvak po prihodu po ovlašćenom revizoru je KPMG. Njegov prihod po revizoru je ove godine iznosio preko milion i po EUR. Iza ove firme, na sledeće tri pozicije su PWC, Deloitte i E\&Y.

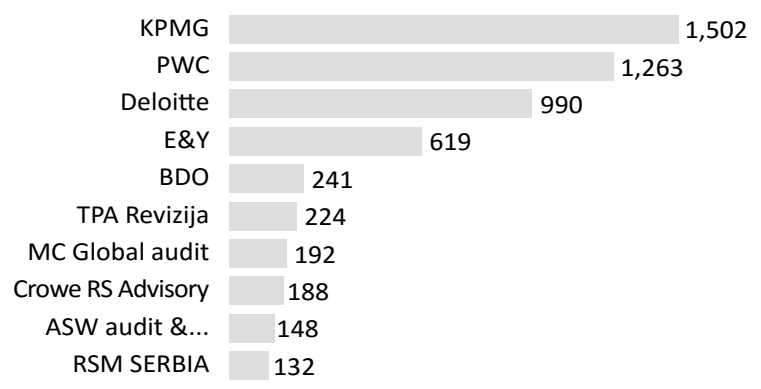

Ovde je V4 na vrhu, izdvojena od svih drugih i u redosledu koji nije istovetan sa redosledom formiranim prema masi realizovanog prihoda. Međutim, primetna je razlika između prvog i četvrtorangiranog. Tu je odnos više nego dva i po prema jedan. Nakon Četvorke su oni koji imaju drastično manje prihoda po revizoru. Prvi u odnosu na četvrtog ima nešto više od njegove trećine. Iza toga se nižu firme sa opadajućim vrednostima.

Raspon po prihodu po ovlašćenom revizoru između prvorangiranog i rangiranog na 10. mestu je preko 11 prema jedan.

\section{KOLIKO JE STABILNA TOP 10 LISTA?}

Naravno da je lista Top 10 promenljiva. Po pravilu, uvek postoji jedan deo njih koji su dugoročnije na listi. To su članovi V4. Uz ove, u prethodnih 10 godina, na ovoj listi su uglavnom: BDO, Moore Stephens, Euroaudit, Finaudit i RSM SERBIA. Logično je da bude fluktuacija na ovoj listi, a te fluktuacije su koncentrisane na mesta iza šeste pozicije.

\section{VELIKA ČETVORKA U SRBIJI 2018.}

\section{Dominacija V4 na tržištu}

Velika četvorka (V4) - KPMG, Deloitte, E\&Y i PWC - u 2018. godini je u Srbiji ostvarila bolje rezultate nego u prethodnoj godinu. Povećala je svoj radijus dejstva, osvojila više prihoda i poboljšala svoju poziciju u odnosu na ostali deo populacije revizorskih firmi Srbije. I ne samo to, ona je zauzela mnogo više tržišta nego u prethodnoj godini. 
U 2018. godini V4 je osvojila 74,5\% prihoda, što znači da je ostalima prepustila samo $25 \%$ tržišta. Dakle, četiri firme - tri četvrtine prihoda; 64 firme - 25\% prihoda. Uz ovo, V4 je u 2018. godini zapošljavala $54 \%$ ljudi, imala $16 \%$ ovlašćenih revizora, sve to od ukupne mase ovih potencijala kojima raspolažu sve revizorske firme Srbije. V4 je u isto vreme operisala sa imovinom koja čini 57\% ukupne

Ogroman je značaj V4 za reviziju u Srbiji, kao što je ona i neporecivo dominantna na tržištu. imovine revizorskih firmi, a angažovala $30 \%$ kapitala i ostvarila $17 \%$ od ukupnih dobitaka revizorskih firmi. Rezultati su zaista impresivni i dovoljni da ukažu na ogromnu moć koju imaju na tržištu usluga revizije i sličnih poslova.

\section{Masa prihoda V4}

V4 ide napred i napred. Tokom 2018. V4 je opet postavila novi rekord $\mathrm{u}$ prihodima $\mathrm{u}$ istoriji revizije $\mathrm{u}$ Srbiji. Njeno učešće je blago spalo sa $75 \%$ u prethodnoj na $76,15 \%$ u ovoj godini. Prvo mesto iz V4 zauzima Deloitte sa 15,8 miliona EUR; na drugom mestu je KPMG sa 15 , sledi PWC sa 8,8, i konačno E\&Y sa $6,2 \mathrm{ml}$. EUR.

KPMG je nakon dužeg niza godina

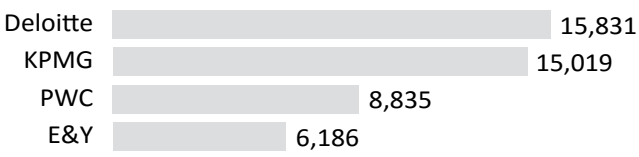
sišao na drugu poziciju, a prvu je zauzeo Deloitte.

Raspodela unutar V4 ukazuje na blagu prednost Deloitte $u$ odnosu na KPMG, raspon u prihodima između prvog i četvrtog na V4 listi je oko 2,5 prema jedan. Treći i četvrti član V4 imaju zajedno nešto više nego Deloitte, koji stoji na prvoj poziciji.

\section{Promene prihoda V4 u 2018. u odnosu na prethodnu godinu}

U celini, V4 je u 2018. godini ostvarila pozitivan rast, dakle, svako pojedinačno je na boljem, i svi zajedno su osvojili mnogo više nego u prethodnoj godini. Deloitte je bio najbolji u masi osvojenog prihoda. On čvrsto drži lidersku poziciju. Međutim najdinamičniji rast $\mathrm{u}$ ovoj godini je ostvario PWC, povećavši prihod za preko petinu; sledi

\begin{tabular}{|c|c|c|}
\hline KPMG & & $\begin{array}{c}1.616 .616 \\
1.755 .208\end{array}$ \\
\hline Deloitte & & $\begin{array}{l}.107 \\
1.654 .218\end{array}$ \\
\hline$E \& Y$ & & $\begin{array}{l}.572 \\
70.252\end{array}$ \\
\hline PWC & $\begin{array}{l}733.431 \\
867.243\end{array}$ & $\begin{array}{l}\text { Prihod } 2016 . \\
\text { Prihod } 2017 .\end{array}$ \\
\hline
\end{tabular}
Deloitte sa preko $13 \%$ rasta; $1,44 \%$ rasta imao je KPMG dok je E\&Y, pao za $15 \%$.

\section{Distribucija prihoda unutar V4}

Članovi V4 međusobno dele prihod u proporcijama koje odgovaraju njihovim sposobnostima i kapacitetima. Dominantno mesto pripada Deloitte, koji zauzima $35 \%$ onog što V4 zajedno prisvoji. Iza nje je KPMG sa 33\%, potom PWC sa $19 \%$ i E\&Y na četvrtom mestu sa $13 \%$. 


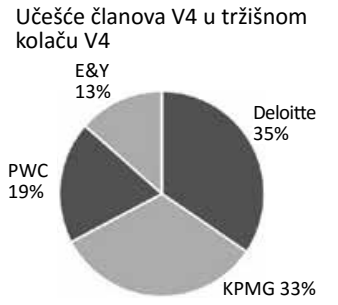

Situacija se promenila $u$ odnosu na prethodnu godinu kada je KPMG imao 31\%, Deloitte 29\%, E\&Y 24\%, a PWC 16\%.

Dakle, promenjen je relativni udeo pojedinih članica V4, uz činjenicu da je prošlogodišnji drugi sada prvi, dok je prošlogodišnji četvrti sada došao na treću poziciju.

\section{Tržišna distribucija prihoda: V4 i ostali}

Odnos u zahvatanju tržišnog kolača koji pripada reviziji u Srbiji, a koji se može posmatrati iz ugla odnosa onog što dobijaju V4

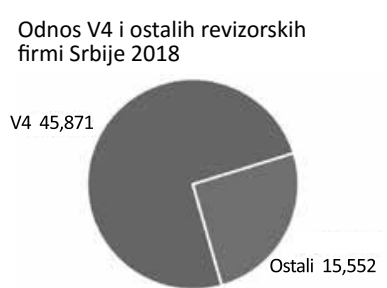
i ostali, daje vrlo instruktivan uvid. Slika ovih odnosa je pod neprekidnim promenama. V4 nije jedinstven entitet, već nju čine ljuti konkurenti koji se izdvajaju od ostalih po tržišnog opsegu usluga. Ako se, uslovno rečeno, ova celina suprotstavi - pokazateljima - ostalima, misleći se pri tome na populaciju ostatka revizorskih kuća, onda se primećuje njihova izrazito jača ekspanzija. Trenutno stanje ukazuje da postoji 68 registrovanih revizorskih firmi, pa u sučeljavanju Velike četvorke (V4) odmerava prema 64. Brojčana nadmoć ovde ne igra nikakvu ulogu, međutim ima smisla porediti ogromnu većinu sa dominantnom V4.

\section{VELIKA ČETVORKA GLOBALNO 2018.}

Accountancy Age (u svom izveštaju o stanju V4 globalno za 2018. godinu iskazuje prihode koje su ostvarili članovi i rangira ih prema tome. Prema tom pregledu, koji je prikazan na grafikonu, V4 je u ovoj godini zaradila 148,6 mlrd USD. Prvak u zaradi

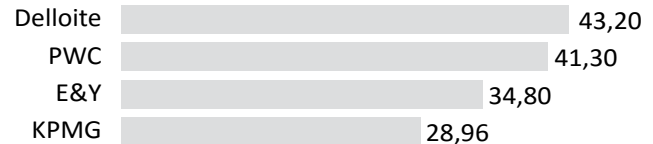
je Deloitte, jer je zaradio 43,2 mlrd USD. Na drugom mestu je PWC, koji za prvakom zaostaje za $1,9 \mathrm{mlrd}$, a zaradio je 34,8 mlrd. Joše osetnije ispod ispod dvojke je E\&Y, zaradio je 34,8 mlrd USD, i kaska za prvakom za 8,3 mlrd USD. Na dnu lestvice je KPMG, koji je zaradio 28,96 mlrd USD, dakle, iza prvog je za 14,3 mlrd USD.

Različitim tempom su rasli članovi V4 u 2018. u odnosu na 2017. godinu. Tako je najvišu stopu ostvario Deloitte $-29 \%$, za njim je PWC $-28 \%$, potom E\&Y - 23\%, a na dnu je KPMG - 20\%.

Očigledna posledica: više stope rasta dvoje prvorangiranih dovele su do jačeg odvajanja ovo dvoje u odnosu na drugu 
dvojku članica V4. Posledica toga su da je Deloitte uvećao svoje učešće u ukupnom kolaču V4 globalno, da ga je PWC neznatno umanjio, a isto to se dogodilo sa E\&Y i KPMG. Dakle, pravi dobitnik trke u 2018. godini između članova V4 je Deloitte.

\section{V4 globalno prethodne dve godine}

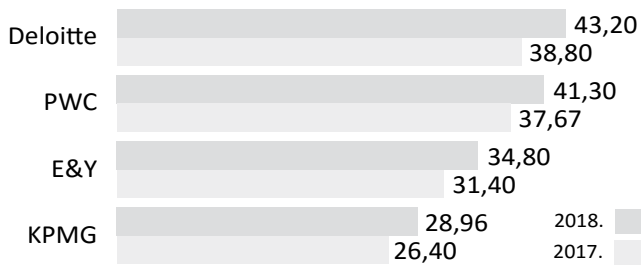

Tabela je konstruisana prema podaciama: https://big4accountingfirms.com/big-4-accounting-firms-ranking/)

\section{LITERATURA}

1. Accountancy Age, Big t Accounting Firms Ranking 2019 - https://big4accountingfirms.com/big-4-accounting-firms-ranking/

2. Finansijski izveštaji revizorskih firmi Srbije objavljeni na: www.apr.gov.rs

3. Miloje A. Milenković, Revizorske firme u Srbiji 2017, REVIZOR, 83/2018

4. World Bank Group (2019), Serbia`s Growth Challenge - http://pubdocs. worldbank.org/en/965791561402546104/Serbia-CEM-NGA-ConceptNote-public-Eng.pdf

5. World Bank Group (2019), Serbia`s New Growth Strategy - http://pubdocs.worldbank.org/en/892631557249265437/Serbia-New-GrowthAgenda-4pager-ENG.pdf

\section{Metodološke napomene}

Izdvajanje prvih 10, odnosno Top 10, vrlo je uobičajen manir stavljanja u fokus onih koji su najznačajniji za populaciju koja se analizira. To činimo i u ovom istraživanju jer sledimo interesovanje za saznanjem rezultata najboljih.

Radi boljeg razumevanja onog što se interpretira u ovom tekstu, dajemo sledeće napomene:

- Parametri po kojima se formira Top 10 lista su oni koji daju najmarkantnija obeležja za razlikovanje unutar revizorskih firmi.

- Prihod koji prikazujemo predstavlja poslovni, a ne ukupni prihod. Razlog za ovakav postupak je činjenica da su poslovni prihodi prava mera poslovnog uspeha revizorskih firmi. lako su „poslovni“, to ne znači da su ostvareni samo od usluga u reviziji, nego i mnogih drugih koji dolaze pod ovu kategoriju.

- Svi poslovni prihodi revizorskih firmi nisu isto što i prihodi od revizije. Mnoge firme imaju niz drugih prihoda koji potiču od poreskih saveta, konsultovanja mnogih vrsta, računovodstvenih usluga, itd. Rangiranje, dakle, ne znači rangiranje samo po prihodima ostvarenih u reviziji. Reč je o iskazima prihoda onih firmi koje su registrovane za obavljanje revizije.

- Sasvim jasno se izdvajaju firme na Top 10 listi po kriteriju prihoda. Međutim, primena drugih kriterija dovodi i neke inferiorne firme u grupu Top 10. Nismo slepo sledili kriterij, već smo učinili intervenciju po kojoj na tu listu ne mogu doći oni koji imaju godišnji poslovni prihod manji od 300 hiljada EUR.

- Svi podaci su uzeti sa sajta APR, koji su opšte dostupni i lako proverljivi. Podaci o globalnoj poziciji V4 su preuzeti od Accountanca Age.

- Za Pareto analizu revizorskih firmi uzeli smo $20 \%$ firmi od ukupno aktivnih 68 , što čini populaciju od 14 revizorskih firmi poređanih po veličini prihoda. 